\title{
«Desde el artificio de la ficción es posible experimentar escenarios políticos futuros»
}

\author{
Una entrevista con Gabriela Zamorano ${ }^{1}$ \\ por Sofía Velázquez Núñez \\ https://doi.org/10.1880o/conexion.201902.001
}

¿Cuál es el valor del pensamiento académico en un momento político como el que atraviesa ahora Latinoamérica?

Eso es algo que siempre me cuestiono pero que, ahora que estuve en Bolivia, apareció de manera más fuerte. ¿Para qué sirve lo que hago en este contexto? Para qué sirven los espacios académicos, intelectuales, educativos... La primera impresión que tuve cuando empezó la movilización contra el fraude fue que las cosas se estaban polarizando mucho.

Había reacciones muy violentas y, para mí, incomprensibles, desde ciertos sectores. Todo el mundo empezó a acusar a los otros: de masistas, de derechistas... Incluso entre gente que se conocía, los ataques aparecían de manera muy visceral. Entonces, hacen falta espacios de escucha y de diálogo; hacen falta espacios educativos en el sentido amplio. Donde la gente se siente a conversar, a pensar lo que está pasando, a escucharse. Estos espacios son los que genera la academia, los que debería generar. Un espacio para humanizar, para hacer preguntas, no tanto para encontrar respuestas. Hace falta entender matices, entender por qué ciertas personas están hablando así. La educación es una trinchera que he asumido desde hace mucho tiempo. Yo siento que la academia y la

\footnotetext{
${ }^{1}$ Licenciada en Comunicación Social por la Universidad Autónoma Metropolitana (1996), maestra en Antropología Social por The New School for Social Research (2000) y doctora en Antropología por The City University of New York. Su área de especialización es la antropología visual. Su actual proyecto de investigación analiza comparativamente la producción y circulación de imágenes fotográficas y audiovisuales relativas a los pueblos indígenas en dos contextos nacionales e históricos distintos en México y Bolivia. Es autora de Indigenous Media and Political Imaginaries in Contemporary Bolivia (Nebraska, 2017) y coautora de De frente al perfil: retratos raciales de Frederick Starr (El Colegio de Michoacán, 2012). Su trabajo académico se complementa con actividades curatoriales de fotografía, colaboración en producción y difusión de video indígena latinoamericano, y proyectos personales de fotografía y video.
} 
intelectualidad son espacios justamente para pensar críticamente, para pensar por qué ciertos discursos se están normalizando y para hacerse preguntas frente a esa normalización. Me parece muy urgente pensar por qué la derecha está ganando tanto terreno, por ejemplo. 0 el porqué de estas reacciones tan fuertes hacia lo indígena si se supone que ya estábamos avanzando en ese sentido.

Entonces creo que aquí tiene cabida hablar sobre la subjetividad como espacio de reflexión...

El tema de la subjetividad es supercomplicado, porque es algo intangible, porque va de cuestiones muy íntimas a cuestiones muy públicas. Porque es contradictoria, ¿no? Porque uno quisiera que un indígena, por ejemplo -a quien le cargamos todas nuestras proyecciones-, sea coherente, que no sea machista, que sea protector de la Madre Tierra, que sea comunitario. Y si no cumple nuestras expectativas nos desilusionamos y decimos que entonces no es lo suficientemente indígena. Creo que la subjetividad implica este espacio íntimo que al mismo tiempo es colectivo; desde donde se crea el sentido común, se crea la norma. Y que también es un espacio muy contradictorio. En ese sentido, la educación es crucial para formar subjetividades y para cuestionar: «¿por qué tengo miedo al indígena?», «¿por qué tengo miedo al otro?» o «¿qué es lo que me está causando estas reacciones?». Estoy hablando de la derecha, pero por supuesto que esto sucede en todos los terrenos. En activismos muy apasionados donde, a veces, tampoco matizamos o cuestionamos y todo es así como «vámonos con esta ola porque en esta ola hay algo que nos fascina, una militancia que nos conmueve». No nos permitimos dar un paso atrás y preguntar.

¿Cómo lees lo que está pasando en Latinoamérica en relación con lo indígena o con este eterno «Otro» que parece desaparecido pero que vuelve a surgir en estos contextos? Pienso, por ejemplo, en Bolivia y esta derecha fascista con mensajes racistas o clasistas directos como «muerte al indio». En el Perú, la situación es similar: hay una frustración contenida, en potencia, latente, que sale a relucir a través de los múltiples conflictos que van surgiendo en el país, principalmente relacionados con el territorio y con las industrias extractivas. Pero esos conflictos son -aparentemente-aplacados a través de asesinatos, criminalización de 
la protesta, pero, sobre todo, a través de la construcción mediática de un «Otro» que es «enemigo del progreso y la modernidad».

En Bolivia me tocó vivir todo el proceso. Algo que me inquietó mucho fue cuando hubo un par de noches muy difíciles después de la salida de Evo. Hubo grupos de los márgenes de La Paz que se lanzaron a atacar instancias muy puntuales: fueron a quemar la casa del rector de la universidad, que estaba con los grupos "pro defensa de la democracia» y en mucha actividad pública contra el fraude. Quemaron los lotes de buses Pumakatari, el transporte público. Y, entonces, empezó el pánico: «Ya vienen las hordas masistas». En realidad, cualquier agrupación de gente que apoyaba a Evo era denominada horda masista. Una de esas noches empezaron a circular mensajes por WhatsApp: «Van a llegar y van a quemar las zonas residenciales y la zona sur. Prepárense: las mujeres vayan al último piso con sus hijos y los hombres bajen con lo que tengan a la mano, con bates, para atacar a las hordas masistas. Vienen de El Alto, de las comunidades aledañas, de Cota Cota...». El discurso era que venían desde los márgenes de la ciudad para atacar a estas clases medias que habían estado luchando por la democracia de manera «racional» y «pacífica». Algunos decían que los mandaban los funcionarios del MAS; otros decían que se organizaban solos. Lo cierto es que había grupos de gente muy enojada por lo que estaba pasando, y que la reacción violenta fue muy específica. Pero eso dio lugar a que se justificaran muchas cosas que llegaron después, incluyendo la militarización, los ataques frontales de los militares hacia las manifestaciones, los asesinatos a bala que no habían sucedido durante el Gobierno de Evo, etcétera. Entonces, yo me quedé pensando mucho en este lenguaje. «iAhí viene la turba, ahí viene la turba, vienen de allá, de allá afuera!». Como si estuvieran llegando los extraterrestres. Y no puedo evitar pensar en la metáfora de los alienígenas en Chile. $\mathrm{Y}$ «iVeo como ocho mil personas y vienen caminando!». Y, al ver las imágenes - no de la televisión, porque ellos sí mostraban turbas, sino de medios independientes-, eran grupos de campesinos organizados, marchando y de manera bastante pacífica.

Todo esto me hizo pensar en un texto que escribí sobre fotografía racial a finales del siglo XIX, principios del siglo XX. El artículo se llama Fisionomía del traidor y revisa fotografías que realizó la expedición francesa Créqui-Montfort en Bolivia. Una de las agendas de esta misión era 
estudiar a los indígenas bolivianos y entender, por ejemplo, su «adaptación a la altura». Era un estudio netamente racial. Llevaron a Bolivia un método de fotografía que inventaron dentro de la criminalística en Francia llamado «método Bertillon», que no es otra cosa que fotografiar de frente y de perfil. La gran parte de personas que fotografiaron para el estudio racial eran aymaras que estaban dentro de la prisión, acusados de matar a «cien soldados». Un abogado que estaba trabajando en este caso decía: «Bueno, lo que pasa es que los aymaras tienen una fisionomía de traidor específica. Porque, por un lado, hacen como que se adaptan al proyecto nacional, pero, por otro, puede resultar que son unos asesinos». Y este discurso viene disfrazado de «legalidad» o de «conocimiento científico», pero, en realidad, es un discurso racial, muy metido en las subjetividades y que tiene mucho que ver con cómo explicó al «Otro». ¿Por su apariencia? ¿Por su fisionomía? Y, a partir de eso, sacó conclusiones sobre su conducta.

Es interesante el texto que comentas. Finalmente, terminamos construyendo al «Otro» a partir de nuestros temores. Construimos primero al monstruo y luego le tememos, ¿no?

Este miedo viene por un desconocimiento. Y esto que te cuento me hizo pensar en una de mis principales preocupaciones: el desconocimiento del Estado Plurinacional. Este es un proyecto que no fue construido por Evo, que no es del MAS. Con el tiempo, Evo y el MAS se apropiaron del indígena, lo movilizaron de manera torpe, generaron cierto cansancio entre otros sectores, incluso entre sectores indígenas que no reconocían o que no respetaban. Vulgarizaron, manosearon la categoría del indígena, como bien dice Silvia Rivera Cusicanqui. Y, finalmente, mucha gente le echa la culpa a Evo Morales: «Arruinaste el proyecto del indígena».

¿Pero que pasa con las clases medias que estaban ahí superactivas y superaguerridas luchando contra el fraude? Muchas de estas clases, que se cruzaron de brazos después de que salió Evo y que se impuso la derecha, muchos de estos sectores que, incluso al principio, pudieron haber votado por Evo Morales, no conocen a los pueblos indígenas ni sus reclamos. Hay un enorme desconocimiento. Nunca entendieron, nunca se sintieron cómodos, nunca hicieron caso o nunca les pareció relevante pensar en Bolivia como un Estado Plurinacional. Y la Asamblea Constituyente 
(convocada en el 2006) fue todo un logro; fue negociación entre muchos pueblos -no solamente aymaras o quechuas-, que extraordinariamente se juntaron a dialogar entre organizaciones que habían estado peleadas, que tenían diferencias. Se juntaron a decir «vamos a construir un proyecto de país». Y la Constitución que resultó es una de las constituciones más avanzadas en América Latina en términos de derechos indígenas. Porque reconoce autonomía, autodeterminación, decisiones y participaciones de los pueblos indígenas en aspectos en los que, generalmente, no son tomados en cuenta, como territorio, manejo de recursos, cuestiones económicas, y que no son solamente el adorno del multiculturalismo. Que Evo se haya brincado muchos procedimientos que dictaba la Constitución en su último mandato no significa que el Estado Plurinacional no haya sido un logro importantísimo. Y muy poca gente está hablando de eso. Entonces, yo creo que acusar a Evo de que hizo todo mal y cruzarse de brazos ante la derecha fue como confirmar que el Estado Plurinacional nunca les ha pertenecido a esos sectores. Entonces, parecía que se estaba avanzando en Bolivia, en términos del clasismo, racismo y, de repente, escucho nuevamente en la calle «indios de mierda». Creo que también tiene que ver también con que, en realidad, no hubo suficiente dialogo ni suficiente esfuerzo por conocer qué era lo que estaban buscando los pueblos indígenas y por reconocerlos como ciudadanos.

\section{¿Y qué crees que pase con ese proyecto?}

Esa es una de las grandes preguntas. De hecho, lo de la wiphala fue como un detonador. Quemar la wiphala fue quemar el proyecto, porque se estableció como símbolo del Estado Plurinacional de Bolivia. Ya se está hablando de reescribir la Constitución y yo creo que lo primero que van a querer hacer es eliminar el Estado Plurinacional.

Por eso la potencia de esa imagen, ¿no? [la imagen de la quema pública de la wiphala en manos de los golpistas]. ¿Cuáles crees que son los discursos que están detrás?

Para mí fue muy impresionante verlo. Tenías a Camacho - representante de la derecha y de sectores oligárquicos de Santa Cruz- entrando al Palacio vacío y colocando en el piso una bandera boliviana y, encima, la Biblia. Y, por otro lado, más o menos en simultáneo, o por lo menos así 
lo viví, unos policías enmascarados sacando la bandera del Palacio. Y, luego, la quema de la bandera. No sucedió de forma continua, pero fue casi una secuencia narrativa. A partir de eso empezaron las movilizaciones, y la «turba» que mencionaba anteriormente llega con banderas diciendo «no van a desconocer la wiphala». Todo termina siendo muy simbólico, Es como decir «aquí no hay indios, aquí no pasó nada». Pero luego llega Camacho, dos días después -creo que después de que Añez tomó la presidencia-, aparece en la tele con la wiphala y con la bandera boliviana y dice: «No, aquí no se discrimina a nadie. Fue un error. No sé quién lo hizo, pero nosotros reconocemos la wiphala». Aquí otra vez el juego de lo multicultural.

Tu línea de investigación está relacionada con todo eso que comentas, con las imágenes, sus repertorios y representaciones. Tienes trabajos sobre la producción audiovisual comunitaria e indígena.

Yo creo que un terreno muy importante - tanto educativo como afectivo- de construcción de subjetividades es justamente el cine, por sus cualidades tecnológicas, porque es masivo, colectivo, por la inmediatez, por lo táctil de la imagen, por esta respuesta más sensorial que genera, ¿no? Y yo creo que mi trabajo es como hacer puentes entre la antropología política y la antropología visual. Es, más específicamente, entender procesos políticos a través de prácticas y producción de medios visuales como la fotografía o el video, entre otros. Entonces, en el libro Indigenous Media and Political Imaginaries in Contemporary Bolivia (2017) la pregunta que me hago es ¿cómo así la producción de video, desde las comunidades y organizaciones indígenas en Bolivia, se convierte en un terreno para la experimentación? Desde el artificio de la ficción, entonces, es posible experimentar escenarios políticos futuros, puestas en escena de otras realidades. Entonces, lo que yo documento etnográficamente son estos espacios creados por la ficción en donde se discuten y negocian representaciones, demandas, sus propios procesos: «Ahora, ¿Cómo vamos a representar a este dirigente? Que sea un poco corrupto. No, mejor que no sea corrupto».

Para mí, es un espacio para crear indigeneidad, a partir de lo que sucede alrededor. ¿Qué es ser indígena? ¿Qué es idealmente ser indígena? ¿Cuáles son los problemas que enfrentan las comunidades indígenas? 
¿Cuáles son los problemas y las contradicciones internas? Porque eso es algo que aparece mucho en las películas, ¿no? El machismo, el hecho de que los hombres no quieren que las mujeres tengan derecho a las tierras o títulos de tierras, por ejemplo.

Entonces, este espacio de producción audiovisual funcionaba como un espacio para imaginar y visualizar futuros políticos distintos de los que los pueblos indígenas tenían en ese momento. Porque en el terreno de la ficción sí aparece la pregunta: «¿Qué pasaría si las mujeres deciden un día que quieren reclamar títulos de tierras? ¿Qué pasaría si, un día, las comunidades que viven peleadas por un límite de tierras se ponen de acuerdo y negocian, logran un acuerdo?». En ese sentido, esos espacios son laboratorios en donde se ensayan futuros escenarios sociales y políticos, tanto fuera de cámara como durante todo el proceso de rodaje. Este espacio extraordinario de imaginación, de artificio, de puesta en escena, que te permite ir más allá de lo que ya conoces, solo lo da el cine.

Y creo que esto tiene que ver también con otra pregunta que me hacías en otro momento sobre cómo se está representando lo indígena en el cine latinoamericano. Yo creo que el cine es un espacio que toma el pulso de mucho de lo que está en el sentido común de la gente, de las esperanzas, de las utopías. Y es muy curioso porque, por un lado, tienes experimentación narrativa, formal, muy interesante y donde siempre aparece el indígena de alguna manera. Por ejemplo, en el cine boliviano es muy difícil hacer cine casi casi sin tocar el tema indígena, ¿no? Y tienes estos espacios como el canal ICE, que es un espacio del Plan Nacional Indígena de Comunicación Audiovisual que es, netamente, hacer cine desde comunidades indígenas. Claro que con ciertos procesos de capacitación y con cierta formación y postura política vinculadas a las fórmulas mantenidas durante mucho tiempo, que funcionan, pero que, a veces, limitan la experimentación... pero finalmente los sujetos indígenas están muy presentes; son películas habladas en lenguas indígenas y son problemáticas directamente relacionadas con lo indígena en espacios urbanos o rurales. Pero, por otro lado, tienes lo que sucede en México y que también sucede en toda Latinoamérica: se reunieron un grupo de cineastas indígenas mexicanas en el Festival de Morelia y, entre otras cosas, dijeron: «El papel de sirvientas ya no nos representa. jImagínense otras películas!, otras historias en las que la mujer indígena tenga otros roles. O sea, 
ya supérenlo, pues, ¿no?». Y yo creo que se referían a Roma, de Cuarón, pero de pronto en el Perú está La teta asustada, de Claudia Llosa y en Bolivia Zona sur, de Valdivia. Hay un montón de películas así. La mujer indígena siempre, siempre, está en el papel de sirvienta y desde ahí se cuenta la historia. Estas mujeres en Morelia decían: «Nosotras estamos haciendo películas, estamos contando otras historias. Algunas no tienen nada que ver con lo indígena, otras sí, pero ya nos encajaron ahí».

¡Pero hay otras formas! Pienso, por ejemplo, en la película Nana, de Luciana Decker. Una jovencita que empieza una película sobe la relación con su nana. Empieza de una manera muy cándida y, a medida que va desarrollando la película, va encontrando todas sus contradicciones y las exhibe en la película. Da cuenta de una tensión racial muy interesante desde una mirada muy íntima. Claro, en el cine boliviano hay toda una tradición desde Sanjinés, que está ahí con su pose todo el tiempo y todo el mundo se pelea con él, pero terminan todos haciendo referencia a su trabajo.

Entonces, tiene que ver con temas de clase y raza este querer ser buena onda. Pero ahí cabe hablar de una falta de educación, otra vez en términos muy amplios. Porque ya hay un trecho andadísimo de cine colaborativo, pero hay una imposibilidad de verlo. Los cineastas que narran desde sus espacios de privilegio no son capaces de reconocer la existencia de este cine y a su respectiva tradición de representación. Es querer ser buena onda, empático, pero sin que nada de eso te confronte, sin atreverse a cruzar la línea, o por lo menos colaborar con otra forma de mirar, como sí lo hace Decker en Nana. Ella pasa esa barrera y dice: «Estoy haciendo esta película, pero, en realidad, me estoy viendo yo misma y me da vergüenza escuchar mi voz, pero a la vez estoy cruzando una frontera de comodidad, donde también me confronto y hago patente que es un tema que me incomoda». En este caso, lo autobiográfico confronta a la directora con sus demonios. Es mirarte al espejo, sacar ahí el archivo familiar, los secretos familiares que te incomodan. Es un ejercicio muy valiente cuando se hace. En vez de seguir reproduciendo con desconocimiento de lo que está pasando en el campo del cine -por ejemplo- indígena porque «si no hay calidad técnica, mejor no». Hace muchos años que se hacen otras cosas. Yo creo que el cine más joven está propinando cosas mucho más interesantes. 